\title{
Functionalization of Chitosan with Maleic Anhydride for Proton Exchange Membrane
}

\author{
Muhammad Ridwan Septiawan', Dian Permana ${ }^{2}$, Sitti Hadijah Sabarwati ${ }^{1}$, \\ La Ode Ahmad ${ }^{1}$, and La Ode Ahmad Nur Ramadhan, ${ }^{1, *}$ \\ ${ }^{1}$ Department of Chemistry, Halu Oleo University, \\ Jl. Kampus Hijau Bumi Tridharma, Anduonou, Kendari 93132, Southeast Sulawesi, Indonesia \\ ${ }^{2}$ Department of Chemistry, Sembilanbelas November University, Kolaka, Indonesia, \\ Jl. Pemuda No. 339, Kolaka 931517, Southeast Sulawesi, Indonesia
}

Received May 19, 2017; Accepted March 9, 2018

\begin{abstract}
Chitosan was modified by maleic anhydride, and it was then functionalized using heterogeneous and blending method to obtain the membrane. The results of the reaction between chitosan with maleic anhydride were signed by the new peak appears around $1475 \mathrm{~cm}^{-1}$ which attributed to $C=C$ bending of the alkene. The new peak also appears at $1590 \mathrm{~cm}^{-1}$ which attributed to $\mathrm{N}-\mathrm{H}$ bending of the amide. Chitosan-maleic anhydride membranes show microstructure of chitosan membrane with high porous density and rigidity while chitosan-maleic anhydride membranes have clusters. In addition, the thermal tenacity of membranes reached $500{ }^{\circ} \mathrm{C}$. Modified membrane by heterogeneous and blending method have higher water uptake, ion exchange capacity, and proton conductivity than chitosan membrane. Moreover, the blending method is much more effective than the heterogeneous method that can be exhibited from ion exchange capacity and proton conductivity values of 1.08-6.38 meq $g^{-1}$ and $1 \times 10^{-3}-1 \times 10^{-2}$ $S \mathrm{~cm}^{-1}, 0.92-2.27 \mathrm{meq}^{-1}$ and $1.53 \times 10^{-4}-3.04 \times 10^{-3} \mathrm{~S} \mathrm{~cm}^{-1}$, respectively. The results imply that modification of chitosan membrane with the addition of maleic anhydride using heterogeneous and blending method can be applied to proton exchange membrane.
\end{abstract}

Keywords: chitosan; membrane; maleic anhydride; heterogeneous; blending method

\section{ABSTRAK}

Kitosan dimodifikasi dengan anhidrida maleat yang selanjutnya difungsionalisasi menggunakan metode heterogen dan metode pencampuran polimer (blend) untuk menghasilkan membran. Hasil reaksi antara kitosan dan maleat anhidrida dtandai dengan munculnya puncak baru sekitar $1475 \mathrm{~cm}^{-1}$ yang merupakan vibrasi tekuk $C=C$ alkena. Puncak baru juga muncul pada $1590 \mathrm{~cm}^{-1}$ yang merupakan vibrasi tekuk N-H amida. Membran kitosanmaleat anhidrida memperlihatkan mikrostruktur membran kitosan dengan kerapatan pori dan kekakuan yang tinggi sedangkan membran kitosan-maleat anhidrida memiliki cluster-cluster. Sementara itu, ketahanan termal membran mencapai $500{ }^{\circ} \mathrm{C}$. Modifikasi secara heterogen dan poli-blend kitosan dengan maleat anhidrida memiliki daya serap air, kapasitas penukar ion (KPI), dan konduktivitas proton yang lebih tinggi dibandingkan membran kitosan $\left(10^{-4} \mathrm{~S}\right.$ $\left.\mathrm{cm}^{-1}\right)$. Bagaimanapun, metode poliblend lebih efektif daripada metode heterogen yang dapat dilihat dari nilai KPI dan

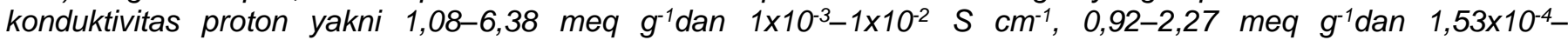
$3,04 \times 10^{-3} \mathrm{~S} \mathrm{~cm}^{-1}$. Hasil menyimpulkan bahwa modifikasi membran kitosan dengan penambahan anhidrida maleat menggunakan metode heterogen dan poliblend dapat diaplikasikan sebagai membran penukar proton.

Kata Kunci: kitosan; membran; anhidrida maleat; heterogen; metode pencampuran polimer

\section{INTRODUCTION}

Many attempts have been made to search and find the way to use energy efficiently as well as to conserve the environment. A fuel cell that can be used as a substitute for rechargeable batteries in portable applications is only Proton Exchange Membrane Fuel Cell (PEMFC). It has a simple system design and easy storage of high energy density fuel [1]. The membrane that used in PEMFC has the negative fixed charge which

* Corresponding author. Tel : +62-81395457770

Email address : laode.ramadhan@uho.ac.id is usually called proton exchange membrane. The performance of this membrane can be increased by modifying the structure of polymer [2].

Some polymer with ionic charge or commonly known as polyelectrolyte can be applied as a proton exchange membrane. During this time the polymer used as a proton exchange membrane for fuel cell applications is sulfonated polytetrafluoroethylene or known as Nafion. It has a $-\mathrm{SO}_{3} \mathrm{H}$ group as a protonexchange group. Nafion has been shown to have a

Muhammad Ridwan Septiawan et al. 
good ability as a proton exchange membrane, but this membrane comprises tetrafluoroethylene that makes it very expensive and dangerous to the environment. Therefore, the development of new alternative proton exchange membranes that will provide improved character, environmentally friendly, and low production cost for fuel cell application is highly required [3].

Chitosan, extracted from shrimp waste, both as dissolved polymer and as cast membrane, has attracted significant interest in many potential applications as a cationic biopolymer and bioactive compound [4]. Chitosan has pointed out that cationic polyelectrolyte such as chitosan has unique character due to the presence of both amine and hydroxyl groups [5-6]. Therefore, it makes chitosan membrane an excellent material to be further developed. In the previous work of our group, chitosan was extracted and characterized from shrimp shell that obtained chitosan with a high degree of deacetylation (DD) [7]

Herein, we extend this work by reporting on maleic anhydride-modified chitosan membrane for proton exchange membrane. As known, maleic anhydride has carboxyl groups that increase the hydrophilic properties of the chitosan membrane. It means that ion exchange capacity increases if the carboxyl groups exist in the membrane. Chitosan was modified by maleic anhydride using both homogeneous and heterogeneous blending methods to improve the ion exchange capacity (IEC) and proton conductivity of proton exchange membrane.

\section{EXPERIMENTAL SECTION}

\section{Materials}

Chitosan with a deacetylation degree of $81 \%$ was obtained from previous research team by Ahmad [8]. Analytical grade reagents use in this paper were acetic acid, $N, N$-dimethyl formamide (DMF), maleic anhydrous, sodium hydroxide, sulfuric acid, acetone, copper(II) sulfate $\left(\mathrm{CuSO}_{4}\right)$ were purchased from the Emsure Merck, Jakarta. De-ionized water was used in all experiments.

\section{Instrumentation}

Fourier transform infrared spectroscopy (FTIR) (Shimadzu 8400) $\left(4,000-500 \mathrm{~cm}^{-1}\right.$, resolution $\left.4 \mathrm{~cm}^{-1}\right)$, differential thermal analysis-thermogravimetric analysis (TGA) Analyzer (Mettler Toledo) (operation condition: 30-550 ${ }^{\circ} \mathrm{C}$ ), Scanning Electron Microscopy (SEM) (Jeol JSM-6360), and Impedance Analyzer (Agilent ${ }^{\mathrm{TM}}$ E4980A).

\section{Procedure}

\section{Homogeneous poly-blend method}

Chitosan membrane solution of maleic anhydride (CSMA) (the first polymer). Chitosan solids weighed as much as $1 \mathrm{~g}$ then dissolved in $50 \mathrm{~mL}$ of $2 \%$ solution of acetic acid. It was stirred until all chitosan soluble (homogeneous). A solution of maleic anhydride was added to mole ratio as chitosan. A solution of maleic anhydride was prepared by dissolving $0.549 \mathrm{~g}$ of solid maleic anhydride in $10 \mathrm{~mL}$ of DMF. The solution mixture was stirred for $24 \mathrm{~h}$ to form a solution CSMA $_{1}$. The same procedure was used for the preparation of the solution dope CSMA that had a mole ratio of maleic anhydride with chitosan of 2, 3 and 4 with a mass of chitosan and maleic anhydride. The dope solution was denoted as $\mathrm{CSMA}_{1}, \mathrm{CSMA}_{2}, \mathrm{CSMA}_{3}$, and CSMA .

Membrane solution of chitosan (CS) (the second polymer). Chitosan solution of $2 \%$ made by dissolving $1 \mathrm{~g}$ of solid chitosan in $50 \mathrm{~mL}$ of $2 \%$ solution of acetic acid that result is called $\mathrm{CS}_{1}$ solution. The same procedure was conducted for the solution of chitosan 3 , 4 and $5 \%$ by weight of each is $1.5 ; 2 ; 2.5 \mathrm{~g}$, respectively. The results were denoted as $\mathrm{CS}_{1}, \mathrm{CS}_{2}$, $\mathrm{CS}_{3}$, and $\mathrm{CS}_{4}$.

The casting of the poly-blend membrane of CSMACS. Chitosan solution (CS) was added to chitosanmaleic anhydride (CSMA) with various mole ratio (Table 1.). Subsequently, the solutions were stirred for $3 \mathrm{~h}$ until homogenous (dope solution). The dope solutions were cast onto petri-dish and dried at room temperature for $72 \mathrm{~h}$. Next, $1 \mathrm{~N}$ sodium hydroxide solution was added to the dry membranes in the petridish several times. The membranes were washed several times with deionized water to neutralized the membranes. As proton exchange application, membranes were soaked onto sulfuric acid for $24 \mathrm{~h}$ and neutralized by water.

\section{Heterogeneous method}

Fabrication of chitosan membrane. Chitosan was weighed as much as $2 \mathrm{~g}$ and then dissolved in $100 \mathrm{~mL}$ of acetic acid of $2 \%(\mathrm{v} / \mathrm{v})$. It was then stirred for $24 \mathrm{~h}$. Subsequently, chitosan solution was filtered and cast onto petri-dish. It was dried at room temperature for $72 \mathrm{~h}$. Next, $1 \mathrm{~N}$ sodium hydroxide solution was added to the dry membranes in the petri-dish several times. To neutralized, the membranes were washed several times with deionized water.

Modification of chitosan membranes. The various mole ratio of chitosan toward to maleic anhydride solutions (1:1, 1:2, 1:3 and 1:4) was poured to chitosan membranes in an Erlenmeyer. Subsequently, it was 
shaken for $24 \mathrm{~h}$. The modified-chitosan membranes were washed with deionized water then with acetone to remove unreacted maleic anhydride. The membranes were then dried at room temperature. The results were denoted as CS-MA 1, CS-MA2, CS-MA ${ }_{3}$, and CS-MA 4 .

\section{Water uptake measurements}

The water uptake of the membrane was determined by measuring the weight difference of membrane before and after immersion in distilled water. Samples of the membrane were dried at room temperature for $24 \mathrm{~h}$ and then weighted (Mdry). The membrane then was immersed in distilled water at room temperature for $24 \mathrm{~h}$. After removing residual water from the surface of the membrane, the membrane was then weighted ( $\left.\mathrm{M}_{\text {wet }}\right)$. The water calculated based on Eq. 1.

Water uptake (\%) $=\frac{M_{\text {wet }}-M_{\text {dry }}}{M_{\text {dry }}} \times 100 \%$

where $M_{\text {wet }}$ and $M_{\text {dry }}$ are the weights of the membrane in the wet and dry states, respectively.

\section{lon exchange capacity (IEC)}

The membranes were cut to size of $3 \mathrm{~cm}^{2}$, then soaked in $50 \mathrm{~mL}$ of $0.01 \mathrm{M} \mathrm{NaOH}$ for $12 \mathrm{~h}$ at room temperature. A total of $10 \mathrm{~mL}$ of $\mathrm{NaOH}$ solution used for soaking the membrane was titrated by $0.01 \mathrm{M} \mathrm{HCl}$ with phenolphthalein indicator. In addition, $10 \mathrm{~mL}$ of $0.01 \mathrm{M}$ $\mathrm{NaOH}$ solution as a blank was also titrated with a solution of $\mathrm{HCl} 0.01 \mathrm{M}$. Ion exchange capacity calculated based on Eq. 2.

$\mathrm{IEC}=\frac{\left(\mathrm{v}_{\text {blanko }}-\mathrm{v}_{\text {sample }}\right) \times[\text { base }] \times f}{\mathrm{~m}}$

where $m$ is the weight of membrane and $f$ is a correction factor.

\section{Proton conductivity}

The membranes were cut to size of $12 \mathrm{~cm}^{2}$. The proton conductivity of fully hydrated membranes was measured as a function of temperature. Measurements were carried out in two point-probe conductivity cells using two platinum wire electrodes as the working electrode. The electric resistance data were obtained using impedance analyzer (Aglient $\left.{ }^{\mathrm{TM}} \mathrm{E} 4980 \mathrm{~A}\right)$ and were recorded between $20 \mathrm{~Hz}-2 \mathrm{MHz}$ at working voltage amplitude of $1 \mathrm{~V}$. The impedance spectra were fitted on ZView 2 software by Scribner Associates Inc. for curve fitting procedure. The proton conductivity values were obtained according to Eq. 3.

$$
\sigma=\frac{S}{R \times A \times L}
$$

where $S$ is a gap of electrodes, $A$ is wide of electrodes, $L$ is the thickness of membrane and $R$ is membrane resistance derived from the low intersection of the high- frequency semicircle on a complex impedance plane with $\operatorname{Re}(\mathrm{z})$ axis.

\section{RESULT AND DISCUSSION}

\section{Fabrication of CSMA, CSMA-CS and CS-MA Membranes}

Though active amino groups and hydroxyl groups are beneficial to grafting reaction, poor water-solubility prevents chitosan from becoming a perfect grafting biomaterial. In general, chitosan is dissolved in acetic acid solution [9-10]. The usage of acetic acid as a solvent may make amino groups of chitosan protonated with no possibility to donate electrons, which makes against side group attachment to amino groups. In this study, both of blending and heterogeneous methods were using inversion phase method with evaporation at room temperature.

The CSMA-CS and CS-MA membranes are obtained from amidation reaction between chitosan, and maleic anhydride in a DMF solvent. The free electrons at the nitrogen atom of amines interact with $\mathrm{C}$ carbonyl of maleic anhydride. Consequently, maleic anhydride undergoes ring opening, and $C$ carbonyl of maleic anhydride binds to the amine group as shown in Fig. 1.

\section{Characterization of CSMA, CSMA-CS and CS-MA Membranes}

The maleic anhydride modified-chitosan was characterized using FTIR, SEM, and TGA. Water uptake, ion exchange capacity, and proton conductivity were measured as well.

\section{FTIR analysis}

FTIR technique was applied to analyze the structural changes in maleic anhydride-modified chitosan directly. Fig. 1 shows FTIR spectra of maleic anhydride-modified chitosan for CSMA, CSMA-CS, and CS-MA membranes.

The analysis was performed on chitosan-maleic anhydride membranes to determine the success of the process of adding maleic anhydride to the chitosan membrane to form of chitosan-maleic anhydride membranes. The addition of maleic anhydride to the chitosan membrane will generate amide functional group on chitosan membrane so that it will change the pattern of the infrared spectra and will bring up the absorption peaks at wave numbers that identify amide groups in chitosan.

The characteristic band at 1558 and $1311 \mathrm{~cm}^{-1}$ are attributed to $\mathrm{N}-\mathrm{H}$ and $\mathrm{C}-\mathrm{N}$ groups $\left(\mathrm{NHCOCH}_{3}\right.$, 

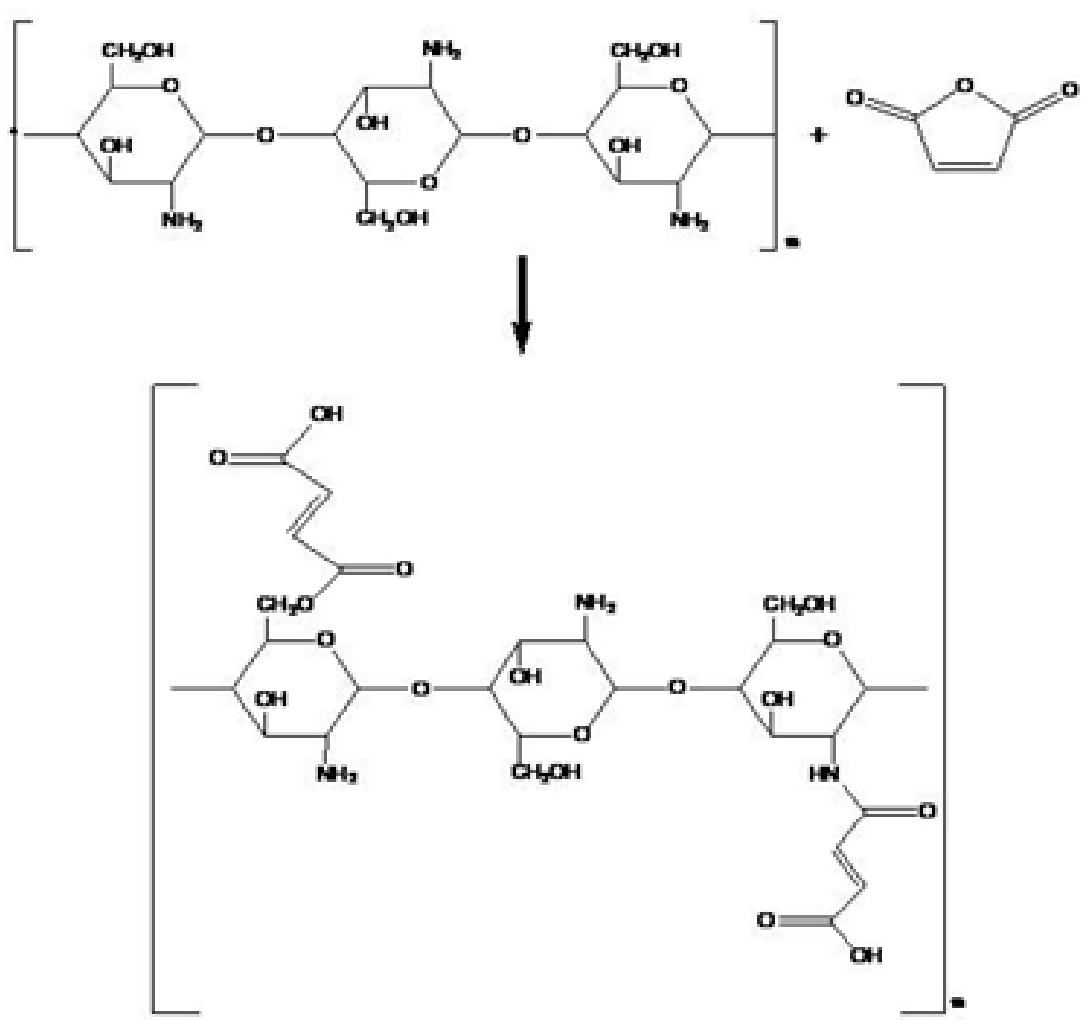

Fig 1. The proposed reaction between chitosan and maleic anhydride
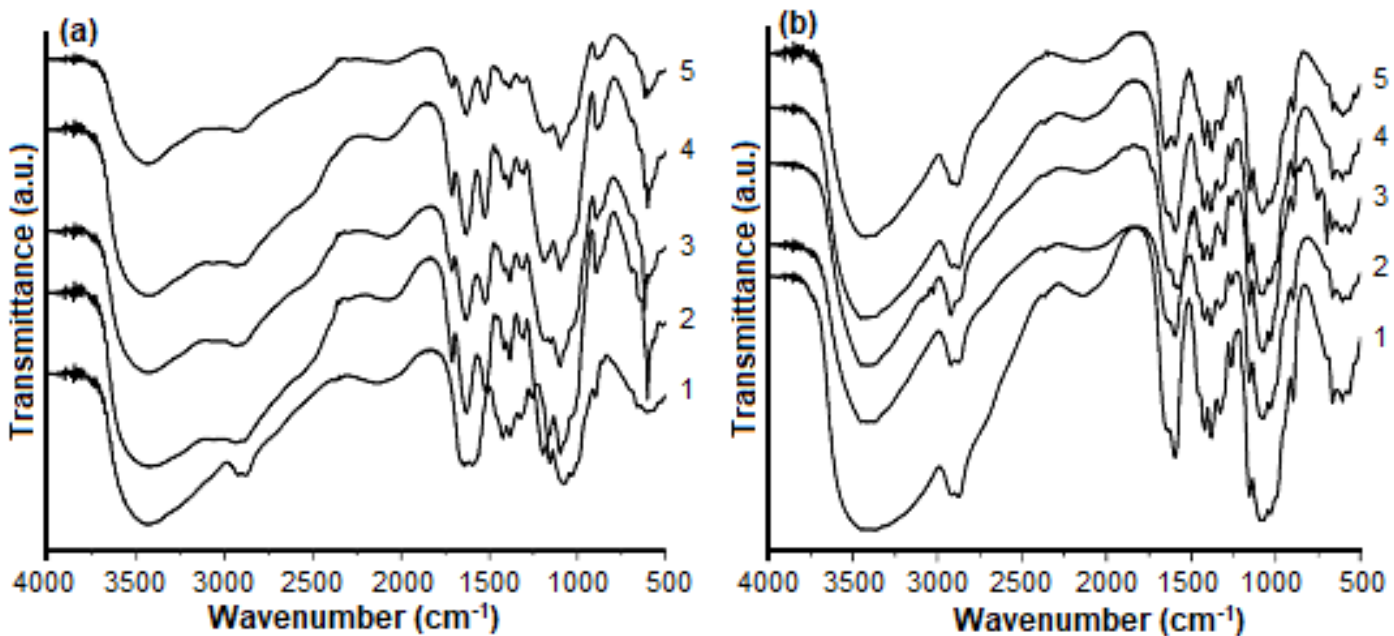

Fig 2. FTIR spectra of functional of chitosan with maleic anhydride for (a). (1. CSMA 1 -CS $1,2 . \mathrm{CSMA}_{1}-\mathrm{CS}_{2}, 3$. $\mathrm{CSMA}_{2}-\mathrm{CS}_{3}$, 4. $\mathrm{CSMA}_{3}-\mathrm{CS}_{3}$, 5. CSMA 4 ) polyblend membranes and (b). (1. CS, 2. CS-MA 1:1, 3. CS-MA 1:2, 4. CSMA 1:3, and 5. CS-MA 1:4) heterogeneous membranes

amide II and III). These increase in absorptions indicate that the maleic anhydride is reacted with chitosan membrane for both blend and heterogeneous methods. The increasing of maleic anhydride which reacted with chitosan membrane lead to the increasing of amide groups contained in chitosan-maleic membranes. The reaction between chitosan and maleic anhydride is supported by the absorption at the peak of $1600-1560$,
$1260-1255$ and $1430-1420 \mathrm{~cm}^{-1}$ which indicated a ringopening reaction of maleic anhydride. In addition, there is also absorption at around $1475 \mathrm{~cm}^{-1}$ which attributed to $\mathrm{C}=\mathrm{C}$ alkenes. Moreover, the absorption band at $1716 \mathrm{~cm}^{-1}$ due to the $\mathrm{C}=\mathrm{O}$ stretching vibration of ester bonds were detected in spectra (a) and (b) (Fig. 2). The intensity of the peak increased with the increase of maleic anhydride amount [11]. Results from the FTIR 

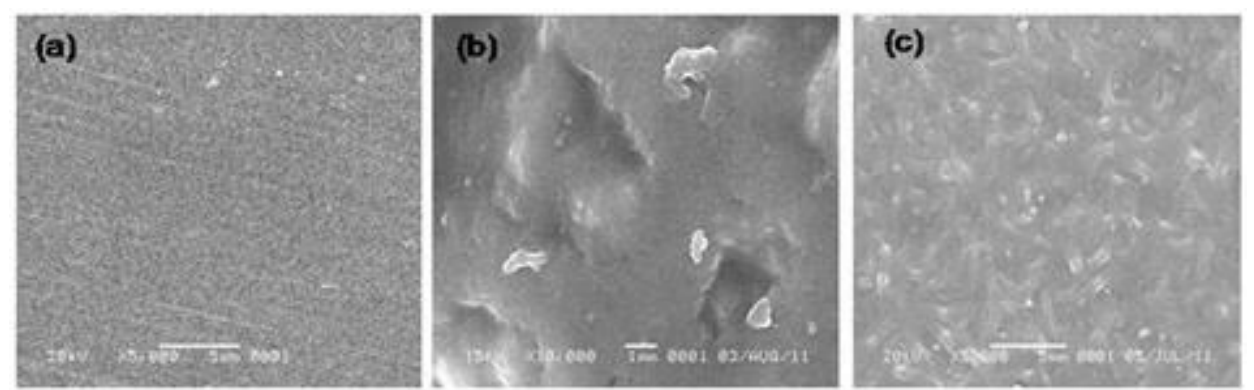

Fig 3. SEM images of membrane: (a) chitosan, (b) $\mathrm{CSMA}_{1}-\mathrm{CS}_{1}$ and (c) CS-MA

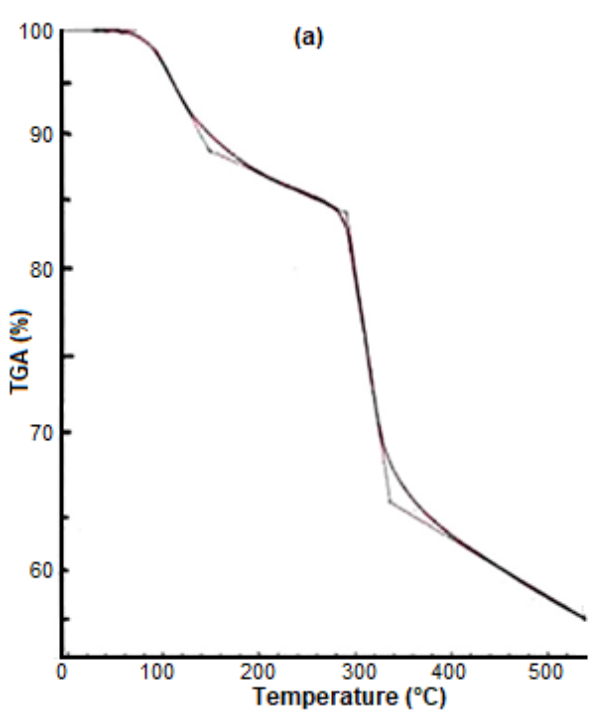

Fig 4. TGA curves of (a) CSMA-CS and

the analysis confirmed that the chitosan-maleic membranes were successfully obtained through the reaction of chitosan with maleic anhydride via ringopening reaction and also ionic crosslinking.

\section{Morphology analysis (SEM)}

SEM micrograph was utilized to further characterize physical structures of chitosan, CSMA-CS, and CS-MA membranes. Fig. 3 shows that chitosan exhibited a flaky nature with relatively rough and small surface, which can be attributed to strong interactions between chitosan molecules. The surface of the polyblend membrane $\left(\mathrm{CSMA}_{1}-\mathrm{CS}_{1}\right)$ and heterogeneous membrane (CS-MA $)_{1}$ are non-porous. In addition, all membranes are homogeneous enough and had no significance for phase dissent.

\section{TGA studies}

The thermal degradation behavior of membranes was examined following the weight loss as a function of temperature. The TGA curves for CSMA-CS and CS-MA membranes are shown in Fig. 4. The TGA curve of CSMA-CS blend membrane (Fig. 4a) exhibits two endothermic transitions at 120 and $400{ }^{\circ} \mathrm{C}$. The

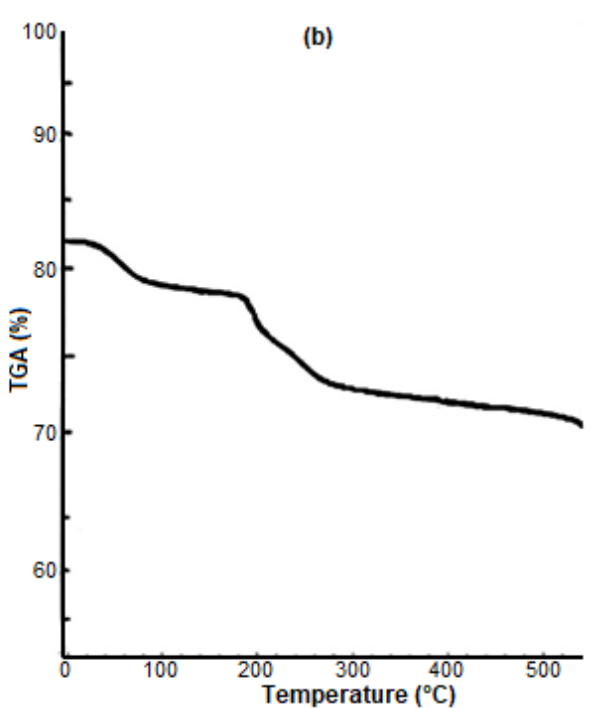

(b) CS-MA membranes temperature $\left({ }^{\circ} \mathrm{C}\right)$

transition at $120^{\circ} \mathrm{C}$ is attributed to the decomposition of a water molecule with weight loss about $12 \%$. The temperature ranging between $140-290^{\circ} \mathrm{C}$ is attributed to the decomposition of amide bond and maleic groups with weight loss about $4.4 \%$. The loss of weight drastically occur at $300-330{ }^{\circ} \mathrm{C}$ and then slowed down at a temperature of $540{ }^{\circ} \mathrm{C}$ with a mass remaining about $54 \%$ that attributed to the decomposition of chitosan polymer [12-13].

The TGA curve of CS-MA (Fig. 4b) shows three weight loss stage in the different temperature range. The decomposition of water molecules occurs at a range between $64.41-107^{\circ} \mathrm{C}$. The temperature at $216-$ $295^{\circ} \mathrm{C}$ is attributed to the decomposition of chitosan and maleic moiety. The decomposition of chitosan polymer also occurs at a range between $300-330{ }^{\circ} \mathrm{C}$ then significantly decreased to $55.5 \%$ of membrane weight at $540{ }^{\circ} \mathrm{C}[12-13]$.

The results of TGA analysis indicate that chitosan reacted with maleic anhydride for both blend and heterogeneous methods. However, the addition of maleic anhydride to the chitosan membrane increasing the thermal resistance of the membrane and reduce the decomposition of chitosan. Chitosan is polymer 
Table 1. Water uptake, Ion Exchange Capacity (IEC) and Proton Conductivity of CSMA-CS and CS-MA membranes

\begin{tabular}{|c|c|c|c|c|c|}
\hline No & Sample & Mole ratio & $\begin{array}{c}\text { Water uptake } \\
(\%)\end{array}$ & $\begin{array}{c}\text { Ion exchange } \\
\text { capacity }\left(\text { meq g }^{-1}\right)\end{array}$ & $\begin{array}{l}\text { Proton conductivity } \\
\left(\times 10^{-3} \mathrm{~S} \mathrm{~cm}^{-1}\right)\end{array}$ \\
\hline 1 & $\mathrm{CSMA}_{1}-\mathrm{CS}_{1}$ & $1: 1: 1$ & 106 & 4.2 & 6.2 \\
\hline 2 & $\mathrm{CSMA}_{1}-\mathrm{CS}_{2}$ & $1: 1: 1.5$ & 150 & 3.8 & 1.8 \\
\hline 3 & $\mathrm{CSMA}_{1}-\mathrm{CS}_{3}$ & $1: 1: 2$ & 165 & 2.1 & 5.0 \\
\hline 4 & $\mathrm{CSMA}_{1}-\mathrm{CS}_{4}$ & $1: 1: 2.5$ & 155 & 1.8 & 3.7 \\
\hline 5 & $\mathrm{CSMA}_{2}-\mathrm{CS}_{1}$ & $1: 2: 1$ & 157 & 6.5 & 2.9 \\
\hline 6 & $\mathrm{CSMA}_{2}-\mathrm{CS}_{2}$ & $1: 2: 1.5$ & 110 & 2.8 & 3.5 \\
\hline 7 & $\mathrm{CSMA}_{2}-\mathrm{CS}_{3}$ & $1: 2: 2$ & 152 & 3.6 & 7.3 \\
\hline 8 & $\mathrm{CSMA}_{2}-\mathrm{CS}_{4}$ & $1: 2: 2.5$ & 118 & 3.7 & 6.3 \\
\hline 9 & $\mathrm{CSMA}_{3}-\mathrm{CS}_{3}$ & $1: 3: 2$ & 102 & 2.2 & 6.8 \\
\hline 10 & $\mathrm{CSMA}_{4}-\mathrm{CS}_{4}$ & $1: 4: 2.5$ & 166 & 2.0 & 3.5 \\
\hline 11 & CS-MA 1 & $1: 1$ & 63 & 0.92 & 1.0 \\
\hline 12 & $\mathrm{CS}-\mathrm{MA}_{2}$ & $1: 2$ & 65 & 1.69 & 1.1 \\
\hline 13 & $\mathrm{CS}-\mathrm{MA}_{3}$ & $1: 3$ & 70 & 1.94 & 1.7 \\
\hline 14 & $\mathrm{CS}-\mathrm{MA}_{4}$ & $1: 4$ & 70 & 2.27 & 3.5 \\
\hline
\end{tabular}
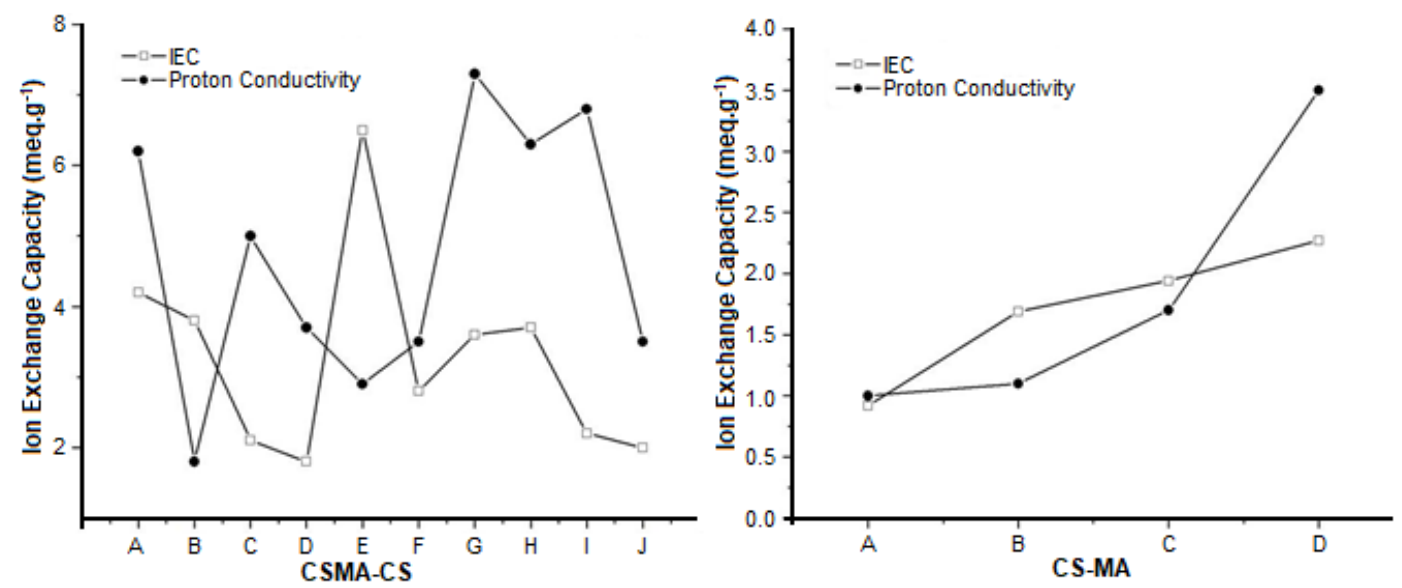

Fig 5. The IEC and proton conductivity curve of CSMA-CS and CS-MA membranes

compound that composed of glucosamine monomer units that need a high temperature for its decomposition.

\section{Water uptake}

Water uptake has an important influence on membrane performance such as proton transport. Water uptake is used to determine the amount of water absorbed by the membrane. Several factors that determine water absorption capability of a membrane are hydrophilic group number and structure of the polymer chain [14]. The homogenous and heterogeneous poly-blends membrane of chitosanmaleic contains hydrophilic groups such as an amine ( $\mathrm{N}$ $\mathrm{H})$, hydroxyl $(\mathrm{O}-\mathrm{H})$ and carbonyl $(\mathrm{C}=\mathrm{O})$. Basically, the present of maleic anhydride makes the structure of polymer opened. It leads the water molecule to diffuse into the membrane more easily. Water uptake of both membranes is shown in Table 1.

Reducing crystallinity of the membrane causes the hydrophilicity of membrane increase and produce greater water uptake. It affects the performance of the membrane in applications as ion exchange membrane. The higher the water uptake leads to higher in proton conductivity due to much more water molecule in the membrane as proton transfer media [15].

\section{Ion Exchange Capacity (IEC)}

Ion exchange capacity (IEC) reveals the number of groups randomly distributed in the polymer chain that capable to exchange the protons in solution. Polyblend membranes are made, the group is expected to support the activity of proton exchange is an amine and hydroxyl groups on the chitosan and the carboxyl group of maleic.

Carboxylate groups are a polar group. Adding the carboxylic group into the polymer chain of chitosan can make chitosan more polar. The increased polarity on chitosan membrane due to increasing the hydrophilic properties of the chitosan membrane. The value of ion exchange capacity increase with the increasing concentration of maleic anhydride that was reacted with chitosan. This relation indicates that the 
hydrophilic properties are directly proportional to the ion exchange capacity. This is due to the chitosan-maleic anhydride membrane ionic groups that support the activity of ion exchange are carboxylic groups $(-\mathrm{COOH})$ [16].

The results of the ion exchange capacity of CSMACS and CS-MA membranes are shown in Table 1. It can be seen that increasing chitosan and maleic anhydride concentration did not obviously clear affect the IEC for CSMA-CS membranes (blend method). It is assumed that when chitosan reacts with maleic anhydride, the $\mathrm{NH}_{2}$ group binds to maleic anhydride thereby reducing the active group acting as a proton exchange medium. The increasing of concentrations increase the number of hydrophilic groups but decrease homogeneity of the membrane by increasing the phase difference. It can be seen from the results of SEM where an increase in membrane phase through form aggregates. The existence of these aggregates reduces the capacity of the ion exchange membrane [17]. The aggregates are formed from the interaction of $\mathrm{NH}_{2}$ groups between the chitosan molecules. Therefore, an increase in the concentration of chitosan reduces the IEC value due to reducing of $\mathrm{NH}_{2}$ groups which can exchange the proton.

The CS-MA membranes (Fig. 5) show the increasing of the IEC value as increasing the maleic anhydride concentration in the membrane. The highest IEC of CS-MA membrane is obtained for CS-MA4 with the IEC value of $2.27 \mathrm{meq}^{-1}$. Based on the data obtained, the chitosan membrane becomes more hydrophilic because the carboxylic group of the maleic anhydride successfully substituted chitosan into the polymer chain. The presence of the carboxylic group on chitosan membranes can act as ion exchangers. Therefore, chitosan membrane can be applied to an ion exchange membrane.

\section{Proton conductivity analysis}

The proton conductivity of CSMA-CS and CS-MA membranes was determined by using the complex impedance method. All impedances were carried out after hydration of the membranes. In the fuel cell system, electricity is generated from proton transfer involving functional groups that can redeem proton thus proton conductivity associated with IEC. In addition, the proton conductivity is also associated with the water uptake for proton transport medium. During measurement, the membrane is wet by the water supplied electric current so that the water molecules adsorbed in the membrane will be dissociated into $\mathrm{H}^{+}$and $\mathrm{OH}^{-}$ions. The $\mathrm{H}^{+}$ions are then bound by a proton exchange group such as $-\mathrm{NH}_{2}$, $\mathrm{OH}$ and $\mathrm{COOH}$ for their ion pairs on the $\mathrm{N}$ and $\mathrm{O}$ atoms, which then migrate and move along the ion exchange groups as a result of the electrical current flowing along the membrane polymer chain. Proton conductivity measurement is the back and forth movement of protons moving in the opposite direction of the original motion [5].

Table 1 and Fig. 5 show that the chitosan modified-membranes have higher proton conductivity values than the chitosan membrane. The results of previous studies have shown that chitosan membrane with a high molecular weight and degree of deacetylation had the proton conductivity of approximately $10^{-4} \mathrm{~S} \mathrm{~cm}^{-1}$. The existence of hydroxyl and amino groups on chitosan framework cause chitosan has high enough hydrophilicity. However, in normal circumstances, chitosan membrane has low electrical conductivity. Chitosan monomer has three atoms of hydrogen in its structure, but the hydrogen atoms are strongly bound to the framework of chitosan and could not be moved under an electric field so that the chitosan film could not be used as proton conductor [6]. However, if the chitosan is dissolved in acetic acid and then were cast as a membrane (thin film), the $\mathrm{H}^{+}$or $\mathrm{H}_{3} \mathrm{O}^{+}$and $\mathrm{CH}_{3} \mathrm{COO}$ ions on chitosan membrane system will spread in the framework of chitosan. These ions can be moved under the influence of an electric field. If the $\mathrm{H}^{+}$or $\mathrm{H}_{3} \mathrm{O}^{+}$ions move more easily than $\mathrm{CH}_{3} \mathrm{COO}$ ion, the chitosan films will be a proton conductor. Chitosan in acidic media can also act as a polyelectrolyte through the protonation of $-\mathrm{NH}_{2}$ groups. The complex was then able to generate an electrical current in the membrane.

\section{CONCLUSION}

In conclusion, functionalization of chitosan with maleic anhydride hydride using both heterogeneous and blending method improved the ability of chitosan membrane as proton exchange membrane. It is supported by the results of analysis of ion exchange capacity, water uptake, and proton conductivity. The addition of maleic anhydride also improves the compatibility of the polymer matrix then increase the polymer matrix interactions. The synthesis of functionalized chitosan with maleic anhydride in this present study paves the way for being a promising candidate in the fuel cell membrane.

\section{ACKNOWLEDGMENT}

The authors are thankful to Ministry of Higher Education Research and Technology of Indonesia for their financial support in Research Competitive Grant No. 063-3/PPK/IV/2014.

\section{REFERENCES}

[1] Haghighi, A.M., Hasani-Sadrabadi, M.M., Dashtimoghadam, E., Bahlakeh, G., Shakeri, S.E., 
Majedi, F.S., Emami, S.H., and Moaddel, H., 2011, Direct methanol fuel cell performance of sulfonated poly (2,6-dimethyl-1,4-phenylene oxide)polybenzimidazole blend proton exchange membranes, Int. J. Hydrogen Energy, 36 (5), 36883696.

[2] Hickner, M.A., Ghassemi, H., Kim, Y.S., Einsla, B.R., and McGrath, J.E., 2004, Alternative polymer systems for proton exchange membranes (PEMs), Chem. Rev., 104 (10), 4587-4612.

[3] Wu, H., Zheng, B., Zheng, X., Wang, J., Yuan, W., and Jiang, Z., 2007, Surface-modified $Y$ zeolitefilled chitosan membrane for direct methanol fuel cell, J. Power Sources, 173 (2), 842-852.

[4] Trung, T.S., Thein-Han, W.W., Qui, N.T., Ng, C.H., and Stevens, W.F., 2006, Functional characteristics of shrimp chitosan and its membranes as affected by the degree of deacetylation, Bioresour. Technol., 97 (4), 659-663.

[5] Cui, Z., Liu, C., Lu, T., and Xing, W., 2007, Polyelectrolyte complexes of chitosan and phosphotungstic acid as proton-conducting membranes for direct methanol fuel cell, J. Power Sources, 167 (1), 94-99.

[6] Salgado, J.R., 2007, Study of basic biopolymer as proton membrane fo fuel cell systems, Electrochim. Acta, 52 (11), 3766--3778.

[7] Ramadhan, L.O.A.N., Radiman, C.L., Suendo, V., Wahyuningrum, D., and Valiyaveettil, S., 2012, Synthesis and characterization of polyelectrolyte complex $\mathrm{N}$-succinylchitosan-chitosan for proton exchange membrane, Procedia Chem., 4, 114-122.

[8] L.O.Ahmad., D. Permana., Wahab., S.H. Sabarwati., L.O.A.N. Ramadhan, and U. Rianse, 2015, Improved chitosan production fromtiger shrimp shell waste (Peneaus monodon) by multistage deacetylation method and effect of bleaching, Advances in Environmental and Geological Science and Engineering, 373-378.

[9] Cheng, M., Huang, Y., Zhou, H., Liu, Z., and Li, J., 2010, Rapid preparation and characterization of chitosan nanoparticles for oligonucleotide, Curr. Appl. Phys., 10 (3), 797-800.

[10] Pillai, C.K.S., Paul, W., and Sharma, C.P., 2009, Chitin and chitosan polymers: chemistry, solubility and fiber formation, Prog. Polym. Sci., 34 (7), 641678.

[11] Chen, Z., Zhang, H., Song, Z., and Qian, X., 2013, Preparation and application of maleic anhydrideacylated chitosan for wet strength improvement of paper, BioResources, 8 (3), 3901-3911.

[12] Fadzallah, I.A., Majid, S.R., Careem, M.A., and Arof, A.K., 2014, A study on ionic interactions in chitosan-oxalic acid polymer electrolyte membranes, J. Membr. Sci., 463, 65-72.

[13] Hemalatha, R., Chitra, R., Rathinam, X.R., and Sudha, P.N., 2011, Synthesizing and characterization of chitosan graft co polymer: Adsorption studies for $\mathrm{Cu}$ (II) and Cr (VI), Int. J. Environ. Sci., 2(2), 805-828.

[14] Kreuer, K.D., 2001, On the development of proton conducting polymer membranes for hydrogen and methanol fuel cells, J. Membr. Sci., 185 (1), 2939.

[15] Peckham, T.J., Schmeisser, J., and Holdcroft, S., 2008, Relationships of acid and water content to proton transport in statistically sulfonated proton exchange membranes: Variation of water content via control of relative humidity, J. Phys. Chem. B, 112 (10), 2848-2858.

[16] Mukoma, P., Jooste, B.R., and Vosloo, H.C.M., 2004, Synthesis and characterization of crosslinked chitosan membranes for application as alternative proton exchange membrane material in fuel cell, J. Power Sources, 136 (1), 16-23.

[17] Zhang, W., Li, G., Fang, Y., and Wang, X., 2007, Maleic anhydride surface-modification of crosslinked chitosan and its pervaporation performance, J. Membr. Sci., 295 (1-2), 130-138. 